\title{
Photocytotoxic lanthanide complexes
}

\author{
AKHTAR HUSSAIN and AKHIL R CHAKRAVARTY* \\ Department of Inorganic and Physical Chemistry, Indian Institute of Science, Bangalore 560 012, India \\ e-mail: arc@ipc.iisc.ernet.in
}

\begin{abstract}
Lanthanide complexes have recently received considerable attention in the field of therapeutic and diagnostic medicines. Among many applications of lanthanides, gadolinium complexes are used as magnetic resonance imaging (MRI) contrast agents in clinical radiology and luminescent lanthanides for bioanalysis, imaging and sensing. The chemistry of photoactive lanthanide complexes showing biological applications is of recent origin. Photodynamic therapy (PDT) is a non-invasive treatment modality of cancer using a photosensitizer drug and light. This review primarily focuses on different aspects of the chemistry of lanthanide complexes showing photoactivated DNA cleavage activity and cytotoxicity in cancer cells. Macrocyclic texaphyrin-lanthanide complexes are known to show photocytotoxicity with the PDT effect in near-IR light. Very recently, non-macrocyclic lanthanide complexes are reported to show photocytotoxicity in cancer cells. Attempts have been made in this perspective article to review and highlight the photocytotoxic behaviour of various lanthanide complexes for their potential photochemotherapeutic applications.
\end{abstract}

Keywords. Medicinal chemistry; lanthanides; photodynamic therapy; DNA photocleavage; photocytotoxicity; confocal imaging.

\section{Introduction}

The lanthanide ( $\mathrm{Ln})$ elements in their stable oxidation state generally form trivalent cations whose chemistry is mainly determined by the ionic radii, which decrease from lanthanum to lutetium. ${ }^{1,2}$ The chemistry of lanthanides differs significantly from the chemistry of main group and transition metal elements because of the $4 f$ orbitals that are spatially 'buried' inside the atom and are shielded from the ligand field. Consequently, the chemistry of the lanthanide ions is largely determined by their sizes. ${ }^{2} \operatorname{Ln}(\mathrm{III})$ forms coordination complexes with a wide variety of ligands. Ln(III) ions are typically hard Lewis acids because of the high charge density and they prefer to bind to hard base atoms, viz. oxygen. Since the $4 f$ electrons are spatially buried, the mixing of ligand and metal orbitals becomes insignificant and bonding between the ligands and the $\operatorname{Ln}(\mathrm{III})$ ions is largely electrostatic in nature. Observation of high coordination number $(>6)$ is due to lack of any directional bonding character and large ionic size resulting poor stereochemical preferences and consequently the coordinating ligands in the complex occupy positions that minimize the steric repulsions between them. Therefore, the coordination environment around the $\mathrm{Ln}$ (III) centre often cannot be regarded as an idealized coordination polyhedron. The trivalent lanthanide ions

*For correspondence barring $\mathrm{La}(\mathrm{III})$ and $\mathrm{Lu}(\mathrm{III})$ have unpaired $f$ electrons and hence are paramagnetic. The magnetic moment values generally deviate from the spin-only values because of strong spin-orbit coupling. The Gd(III) ion has the maximum number (seven) of unpaired electrons with a magnetic moment of $7.94 \mu_{\mathrm{B}}$, but the largest magnetic moments $\left(10.4-10.7 \mu_{\mathrm{B}}\right)$ are exhibited by Dy(III) and $\mathrm{Ho}$ (III) as a result of orbital contribution to the magnetic moment. In Gd(III), all the seven electrons have parallel spins and this high paramagnetism combined with a reasonably slow electronic relaxation rate makes Gd(III) complexes of macrocyclic organic ligands ideally suitable as contrast enhancement agents in clinical magnetic resonance imaging (MRI). Lanthanide ions differ from the $d$-block elements with small crystal field splitting. The spectroscopic properties of the $\operatorname{Ln}(\mathrm{III})$ ions are unique due to shielding of the $4 f$ orbitals by the filled $5 s^{2}$ and $5 p^{6}$ sub-shells. The electronic transitions within the $4 f$ orbitals are Laporte forbidden. Besides, coupling with molecular vibrations is weak and the electronic spectra of lanthanide ions show very low molar extinction coefficients $\left(\varepsilon<10 \mathrm{M}^{-1} \mathrm{~cm}^{-1}\right)$ with narrow absorption bands. Therefore, the absorption spectra of lanthanide complexes are generally characteristics of ligand-centred absorption bands which are often very strong and most of the photophysical properties of the coordinating ligands are retained on complexation with a lanthanide ion. This is particularly true for La(III) $\left(f^{0}\right.$, diamagnetic) and $\mathrm{Gd}(\mathrm{III})\left(f^{7}\right.$, paramagnetic) complexes since both the ions absorb in the UV region. 
The lanthanides significantly enhance the intersystem crossing efficiency of the ligands forming long-lived triplet state due to heavy atom effect. This has important consequences in the chemistry of photodynamic therapy (PDT) where efficacy of a photosensitizer depends largely on the rate of formation of the triplet state.

\section{Therapeutic applications}

Lanthanide complexes are of considerable interests for their therapeutic utility providing strong impetus to explore their biological activities. ${ }^{3-9}$ A brief account of the various therapeutic applications of lanthanides is presented below.

\subsection{Lanthanum carbonate to treat hyperphosphatemia}

Hyperphosphatemia is an electrolyte disturbance resulting from high level of phosphate in the blood. ${ }^{5,8}$ The serum phosphate level in the end stage renal disease (ESRD) patients is thus higher compared to the healthy individuals. The average dietary phosphate intake is ca. $1.0-1.5 \mathrm{~g} /$ day. Under normal conditions phosphate is absorbed in the intestine and excreted via the kidney without retaining excess phosphate. Lanthanum carbonate sold as Fosrenol ${ }^{\mathrm{TM}}$ is used in diet to prevent absorption of the dietary phosphate. $\mathrm{La}(\mathrm{III})$ binds strongly to $\mathrm{PO}_{4}^{3-}$ forming insoluble lanthanum phosphate thus preventing the absorption of dietary phosphate in ESRD patients. $^{5}$

\section{$2.2 G d(I I I)$ chelates as MRI contrast agents}

The most successful medicinal utility of lanthanides is the use of $\mathrm{Gd}(\mathrm{III})$ complexes as MRI contrast agents in clinical radiology. ${ }^{10-15}$ MRI enables the acquisition of high resolution, 3D images of the distribution of water in vivo and these images are significantly enhanced by the use of $\mathrm{Gd}(\mathrm{III})$ contrast agents that decrease the relaxation rate of protons of water coordinated to the paramagnetic metal centre. About $30-40 \%$ of the clinical MRI scans are performed using Gd(III) contrast agents. Paramagnetic Gd(III) ion with seven unpaired electrons and a symmetric ground state $\left({ }^{8} \mathrm{~S}_{7 / 2}\right)$ has high magnetic moment with suitable electronic relaxation rate. An increase in the relaxation rate of water protons results significant enhancement of their signal intensity. However, free Gd(III) at high concentration is toxic. Therefore, Gd(III) chelates are used that are thermodynamically highly stable and kinetically inert. Examples of MRI agents are $\left[\mathrm{Gd}(\mathrm{DTPA})\left(\mathrm{H}_{2} \mathrm{O}\right)\right]^{2-}$ (known as Magnevist ${ }^{\mathrm{TM}}$ ) and $\left[\mathrm{Gd}(\mathrm{DOTA})\left(\mathrm{H}_{2} \mathrm{O}\right)\right]^{-}$(known as Dotarem $\left.^{\mathrm{TM}}\right)$, where DTPA is diethylenetriaminepentaacetate and DOTA is 1,4,7,10-tetraazacyclododecane1,4,7,10-tetraacetate (figure 1).

\subsection{Luminescent complexes as optical probes}

The parity forbidden $f$ - $f$ transitions in lanthanide complexes generally result in very long lived excited states. These long lived excited states of $\mathrm{Ln}$ (III) ions facilitate 'time-gated' emission experiments resulting in significant improvement in the signal to noise ratio compared to the steady-state measurements. ${ }^{1,2,16-25}$ Unfortunately, the forbidden nature of the $4 f$ transitions makes direct absorption of $\mathrm{Ln}$ (III) ions very weak resulting in very low molar absorption coefficients $\left(\varepsilon<10 \mathrm{M}^{-1} \mathrm{~cm}^{-1}\right)$ thus limiting their practical applications.

This problem can be circumvented by using organic chromophoric ligands bound to the luminescent $\mathrm{Ln}$ (III) ion acting as 'antenna' by absorbing incident light and then transferring the excitation energy to the $\operatorname{Ln}(\mathrm{III})$
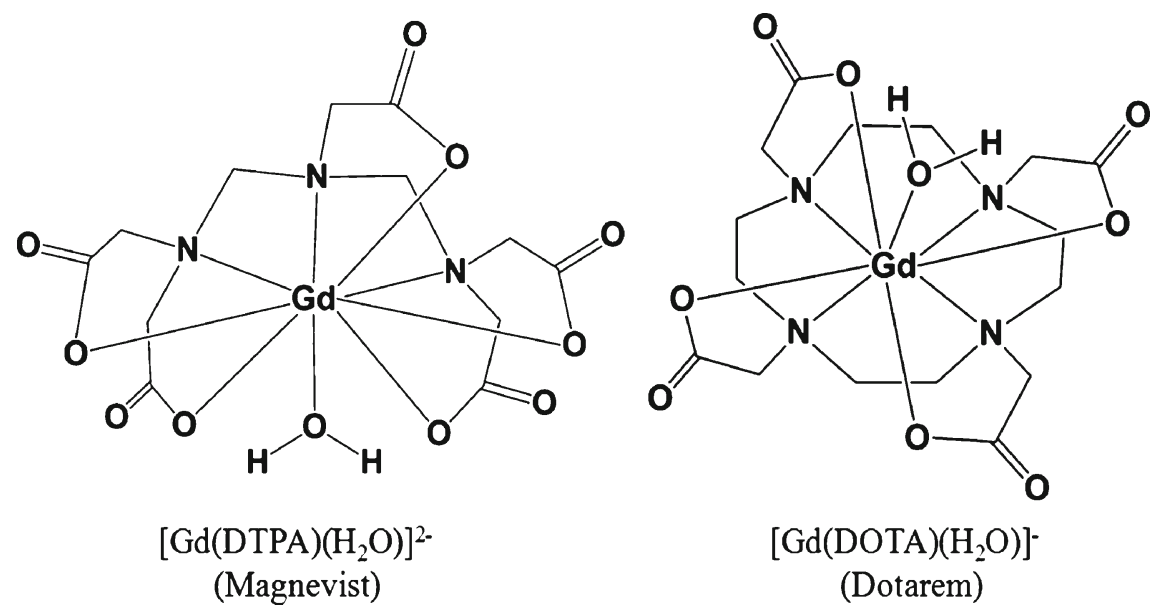

Figure 1. Structures of two clinically used Gd(III)-based MRI contrast agents. 


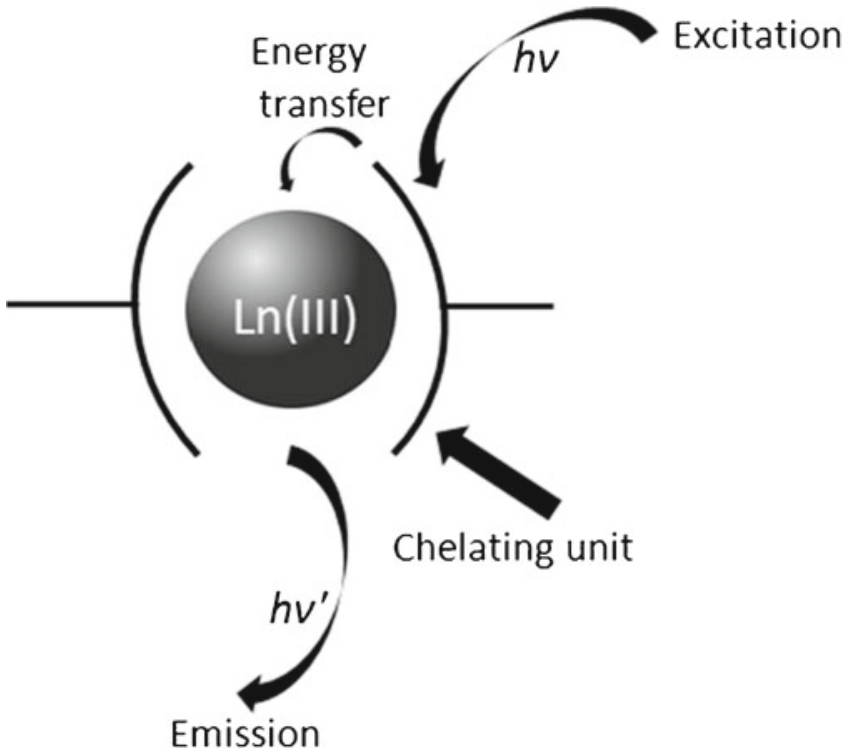

Figure 2. A pictorial representation of the antenna effect for lanthanide luminescence.

ion which subsequently undergoes radiative deactivation resulting in the metal-centred emission which is characteristic of a particular Ln(III) ion (figure 2). For example, Eu(III) shows characteristic red emission, while $\mathrm{Tb}$ (III) shows green emission. The deeply buried nature of the $4 f$ orbitals results in the characteristic narrow 'line-like' emission bands. Parker et al. reported $\mathrm{Eu}(\mathrm{III})$ and $\mathrm{Tb}(\mathrm{III})$ complexes having tetraazatriphenylene chromophores which show remarkable properties for the ratiometric detection of bio-analytes in living cells (figure 3). ${ }^{16-20}$ Similarly, Raymond et al. developed luminescent $\mathrm{Eu}(\mathrm{III})$ and $\mathrm{Tb}$ (III) complexes having 1,2-HOPO (1-hydroxypyridin-2-one) and IAM (2-hydroxyisophthalamide) as chromophoric ligands. . $3,36,27^{2}$

\section{Photocytotoxic lanthanide complexes}

Compounds showing photoactivated cytotoxicity are of considerable importance for their selectivity in killing cancerous cells over the normal cells. When compared to the $3 d-5 d$ metal complexes, there are only few reports on the lanthanide complexes showing photoinduced biological activity and there is considerable scope to expand the chemistry of photocytotoxic lanthanide complexes.

\subsection{Photodynamic therapy (PDT)}

Photodynamic therapy is a novel approach for selective damage of the cancer cells by using light leaving unexposed healthy cells unaffected (figure 4). ${ }^{28-31}$ The advantage of PDT over other conventional therapeutic methods is that the drug is not active until irradiated. Light of wavelength in the range of $620-850 \mathrm{~nm}$ is required in PDT to activate the drug molecule. Absorption of light by a photosensitizer causes an electronic transition promoting an electron from a ground state orbital to an excited state which is relatively shortlived (typically $10^{-12}-10^{-6} \mathrm{~s}$ ) and there exists several pathways for the deactivation of the excitation energy. Initial excitation of the photosensitizer (PS) takes it to a higher vibrational level of the first electronic singlet excited state. The excited molecule then reaches the lowest vibrational level of the first electronic singlet excited state (called $S_{1}$ ) by a process known as internal conversion (IC). At this stage, the PS may undergo further deactivation with the emission of a photon (fluorescence) and comes back to the ground state. Alternatively, the excited singlet $\left(S_{1}\right)$ state may populate the lower energy triplet excited state $\left(T_{1}\right)$ by a process termed as intersystem crossing (ISC). This triplet excited state is of importance in PDT for its

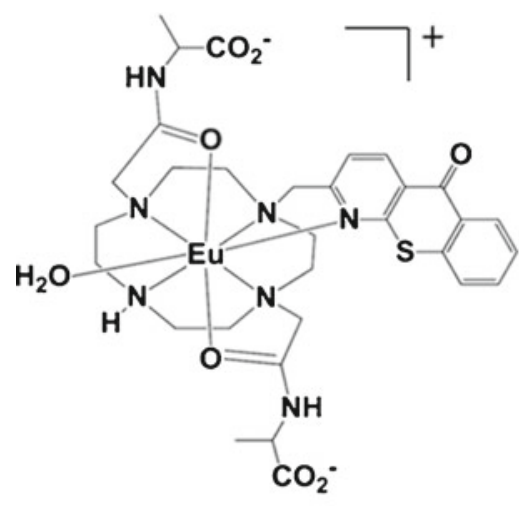

Thiaxanthone

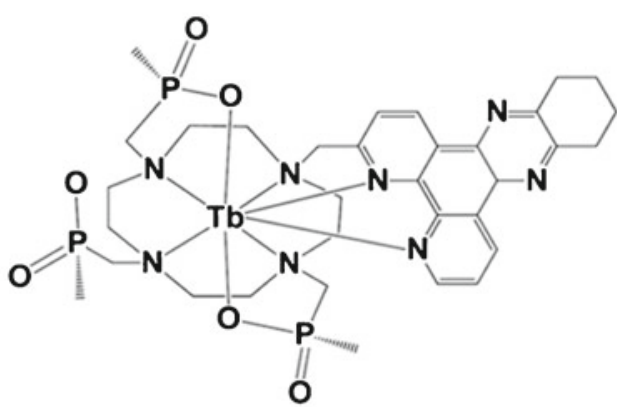

Tetraazatriphylene

Figure 3. Structures of two luminescent Ln(III) complexes having light harvesting chromophores. 

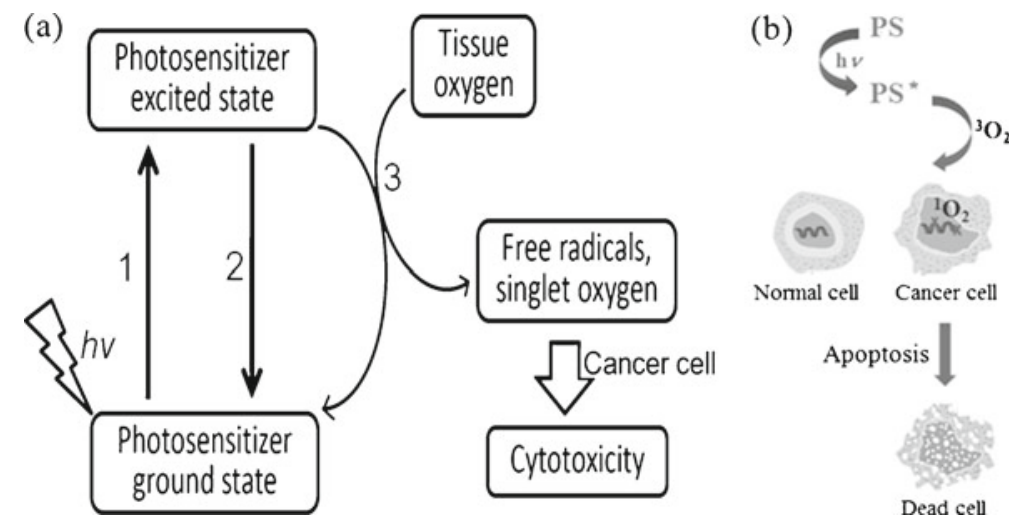

Figure 4. Schematic diagram showing various processes that occurs in photodynamic therapy: 1, light absorption; 2, radiative or nonradioactive decay of excitation energy; 3, energy transfer from the photosensitizer to singlet oxygen.

longer lifetime. ${ }^{32}$ The PS in its triplet excited state can react with molecular oxygen in its triplet state to produce reactive oxygen species, viz. singlet oxygen (in type-II mechanism) or can damage a biological substrate by directly reacting with the organic moiety (in type-I mechanism). Transfer of electron to the molecular oxygen results in the formation of reduced oxygen species like $\mathrm{O}_{2}^{-}$or $\mathrm{O}_{2}^{2-}$. The various processes that can undergo upon irradiation of a PS are described in a modified Jabłoński diagram which is shown in figure $5 .{ }^{33}$ Photofrin ${ }^{\circledR}$, a porphyrin-based FDA approved PDT drug, produces singlet oxygen $\left({ }^{1} \mathrm{O}_{2}\right)$ on photoactivation in red light of $633 \mathrm{~nm} .{ }^{28}$ The problems associated with photofrin are its prolonged skin sensitivity and hepatotoxicity. ${ }^{34,35}$ Organic macrocyclic PDT agents such as porphyrins and phthalocyanines show photocytotoxicity generating cytotoxic singlet oxygen as the active species in a type-II pathway and the efficacy of these PDT agents depends primarily on the quantum yield of singlet oxygen generation. ${ }^{36,37}$ The recently reported metal-based PDT agents, in contrast, could undergo type-I and/or photo-redox pathway in addition to the type-II process. ${ }^{38-45}$
Ln(III) complexes with their poor stereochemical preferences and high coordination numbers provide ample scope for designing PDT active species using photoactive organic ligands to achieve efficient oxidative DNA cleavage activity and photocytotoxicity. $\mathrm{Ln}$ (III) complexes are also expected to be non-toxic in dark owing to the redox stability of the Ln(III) ions thus making them suitable for cellular applications in the presence of reducing cellular glutathione. The presence of heavy lanthanide metal is likely to facilitate the ISC due to heavy atom effect thereby contributing to the efficient generation of singlet oxygen for better PDT effect of the complexes.

In PDT, the cells usually undergo two distinct types of cell death. ${ }^{46}$ The first type is known as necrosis in which the necrotic cellular contents spill into the extracellular medium through the damaged plasma membrane resulting an inflammatory response. Necrosis, as accidental unprogrammed cell death, is caused by physical and/or chemical damage and decomposition is primarily mediated by proteolytic activity. Apoptosis, a programmed cell death, is better characterized by cell shrinkage, blebbing of the plasma membrane and

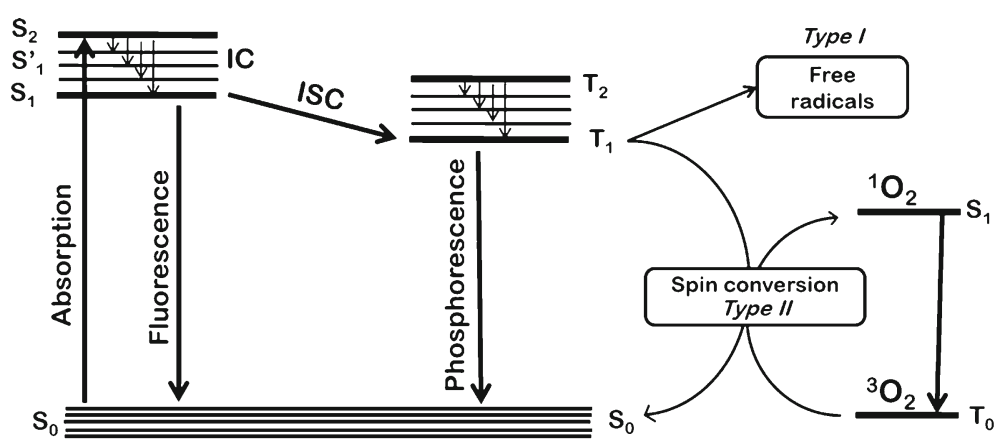

Figure 5. Simplified Jabłoński diagram showing various physical and chemical processes involved in PDT. 
chromatin condensation. In apoptosis, the organelles and plasma membrane retain their integrity for a long period. ${ }^{47,48}$ In vitro, apoptotic cells are fragmented into multiple membrane-enclosed vesicles known as apoptotic bodies and in vivo, these apoptotic bodies are consumed by macrophages preventing further inflammation. In general, it is believed that lower dose in PDT leads to more apoptosis, while higher doses lead to more necrosis. ${ }^{49,50}$

\subsection{Macrocyclic lanthanide complexes: the texaphyrins}

Texaphyrins and their metal complexes have received considerable interests due to their rich photophysical properties and their utility in PDT. ${ }^{5}$ Texaphyrins are coloured pentaaza Schiff base macrocyclic compounds having similarity to porphyrins. The texaphyrins are monoanionic ligands containing five $N$-donor atoms in its central core which is approximately $20 \%$ larger than that of the porphyrins thus enabling them to form stable 1:1 complexes with larger metal ions such as Ln(III). Texaphyrins are generally resistant to oxidation and more susceptible to reduction thereby making them more redox active in a biological environment. In addition, the texaphyrins absorb light of near-IR wavelength $(>700 \mathrm{~nm})$. This property allows for greater tissue penetration of the activating light thereby making them ideal PDT agents.

The promising photo-activated anticancer activity of lanthanide texaphyrins complexes has led to the clinical trials for the treatment of various cancers. ${ }^{5,51-54}$ Gadolinium and lutetium texaphyrins have been used for the treatment of brain metastases of lung cancer and atherosclerotic plaque in coronary heart disease and to treat age-related macular degeneration (AMD). ${ }^{8,51}$ Selected structures of these complexes are shown in figure 6. The redox active Gd-texaphyrin complex, motexafin gadolinium (MGd), has been studied as a

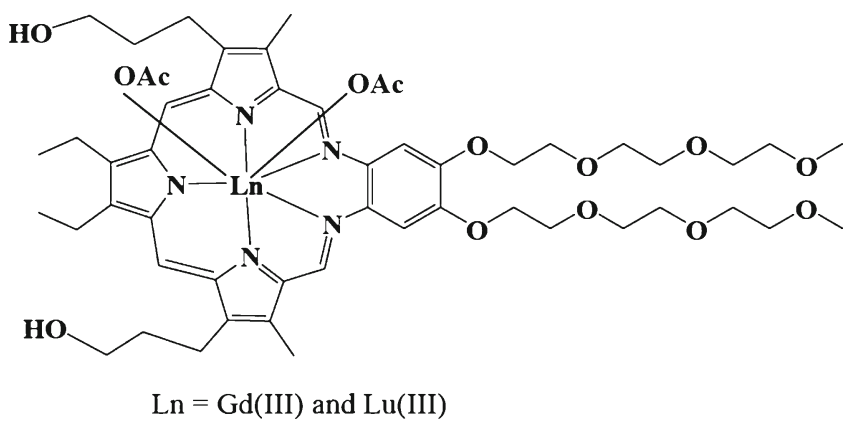

Figure 6. Chemical structure of texaphyrin $\mathrm{Ln}(\mathrm{III})$ complexes. radio- and chemo-sensitizer for the treatment of cancer. ${ }^{55}$ It is reported that MGd can accept electrons from radicals resulting in the reduction of the MGd complex. In the absence of $\mathrm{O}_{2}$, MGd can mediate the formation of hydroxyl radicals. Alternatively, in the presence of oxygen, the electron capture results in a reduced Gdtexaphyrin complex which acts as an electron donor, reacting with $\mathrm{O}_{2}$ to form the superoxide anion. ${ }^{5,51} \mathrm{MGd}$ can react with various intracellular antioxidants to generate reactive oxygen species (ROS) which could react with essential cellular components leading to cell death. MGd catalyses the oxidation of ascorbate and NADPH under aerobic conditions resulting cytotoxicity towards MES-SA and A549 tumour cell lines. This is attributed to an increase in the intracellular ROS caused by MGd which leads to cell death by induction of apoptosis. ${ }^{56}$ MGd is shown to localize selectively in tumour cells as evidenced from the MRI studies of the highly paramagnetic MGd complex. Brain metastases, commonly caused by lung cancer, are unsuitable for surgical procedures and therefore the radiation therapy is the preferred mode of treatment. ${ }^{57,58}$ The survival time of the patients with the whole-brain radiation therapy is about 4 months. Neurologic and systemic disease progression of the brain metastases are the common cause of death of the patients. A combination treatment with MGd has resulted in a significantly improved time to neurologic progression ( $\sim 4.3$ months) compared to the whole brain irradiation alone (3.8 months). MGd has shown positive results in combination with whole brain irradiation to treat brain metastases.

As mentioned above, the absorbance of dark green coloured texaphyrins falls in the near IR light of $>700 \mathrm{~nm}$ that allows greater tissue penetration. The lutetium-texaphyrin complex commonly known as Motexafin lutetium (MLu) has been extensively studied as a metal-based photosensitizer for PDT. ${ }^{5,51,52}$ Like MGd, MLu also selectively localizes in tumour tissues and the complex has entered clinical trials for the treatment of metastatic skin and breast cancer. The complex MLu is also clinically used for the treatment of age related macular degeneration (ARMD), a disease of the eye retina. The complex completed the Phase-I clinical trial in patients with coronary artery disease. ${ }^{59}$ The Phase-I study has revealed that the procedure is safe and suitable of PDT applications. Light-activated motexafin lutetium complexes are currently under development for the treatment of vulnerable plaque.

Lanthanide texaphyrins have also been tested for their ability to cleave DNA in the presence of light. Sessler and co-workers studied the DNA photocleavage activity of lutetium(III) texaphyrin (LuTx) complex on irradiation with near-IR light of $>700 \mathrm{~nm}$ (figure 7). ${ }^{60}$ 

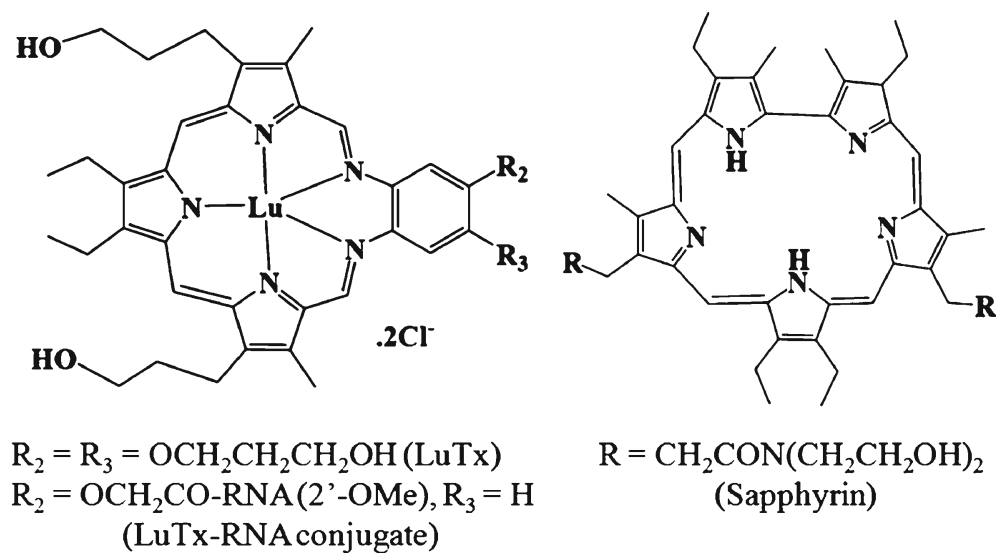

Figure 7. Chemical structures of some texaphyrin lanthanide complexes showing near-IR light DNA photocleavage.

At shorter wavelengths, all three compounds, viz. porphyrin control, sapphyrin, and LuTx, are efficient photocleavers of DNA, but in the near-IR light of $>700 \mathrm{~nm}$, the cleavage efficiencies are $8 \%, 17 \%$ and $93 \%$, respectively. Radical quenching experiments showed the formation of singlet oxygen as the reactive species. The LuTx complex is known to bind via the minor groove of the duplex DNA, although the authors observed some cleavage across the adjacent major groove also. Parker and co-workers reported the pBlueScript plasmid DNA photocleavage activity of macrocyclic Eu(III) and $\mathrm{Tb}$ (III) complexes in UV-A light of $350 \mathrm{~nm} .{ }^{61}$ The complexes are thus of importance for therapeutic applications in the treatment of accessible tumours like skin melanoma.

\subsection{Photoactive non-macrocyclic lanthanide complexes}

Lanthanide complexes of non-macrocyclic ligands have recently been studied mainly by our group as photocytotoxic agents that show DNA photocleavage and photoactivated anticancer activity. ${ }^{62-66}$ In contrast to the chemistry of macrocyclic texaphyrin complexes, the chemistry of photoactive non-macrocyclic lanthanide complexes is virtually unexplored. We have designed Ln(III) complexes to achieve efficient DNA cleavage activity and photocytotoxicity on exposure to light. The complexes with planar photoactive ligands that are coordinated to the metal centre have the ability to generate ROS upon photo-irradiation in an aqueous environment. The complexes offer opportunities to design tumour targeted ligands for cellular application due to their heteroleptic nature. As mentioned above, the presence of a heavy lanthanide element significantly enhances the ISC efficiency and hence the generation of singlet oxygen during PDT. The redox inactive $\mathrm{Ln}$ (III) ions reduce the undesirable dark toxicity in PDT. The photoactivated anticancer and DNA cleavage activity of these complexes are discussed in the following sections based on the ligand systems used. The studies have been carried out by choosing $\mathrm{La}(\mathrm{III})$ and $\mathrm{Gd}(\mathrm{III})$ as representative lanthanide metal ions considering therapeutic importance of these two metal ions.

\section{3a Photoactive complexes of phenanthroline} bases: Metal complexes of 1,10-phenanthroline and extended phenanthroline bases are well-documented in coordination chemistry for their various therapeutic applications. ${ }^{67}$ Extended phenanthroline bases, viz. dipyridoquinoxaline (dpq) and dipyridophenazine (dppz), are used as ligands for many metal ions because of their rich photophysical properties. ${ }^{68}$ The choice of dpq and dppz is based on the fact that these ligands are known to generate photo-excited ${ }^{3}\left(n-\pi^{*}\right)$ and/or ${ }^{3}\left(\pi-\pi^{*}\right)$ state cleaving DNA on irradiation with UV light. ${ }^{69}$ Lanthanide complexes with their varied coordination geometries could be suitably designed to achieve oxidative DNA cleavage activity and poor chemical nuclease activity in the presence of cellular thiols and high photocytotoxicity in cancer cells. We recently reported lanthanide complexes of the formulations $\left[\mathrm{La}(\mathrm{L})_{2}\left(\mathrm{NO}_{3}\right)_{3}\right]$ and $\left[\mathrm{Gd}(\mathrm{L})_{2}\left(\mathrm{NO}_{3}\right)_{3}\right]$, where $\mathrm{L}$ is a $N, N$-donor phenanthroline base, viz., 1,10-phenanthroline (phen), dipyrido[3,2$\left.d: 2^{\prime}, 3^{\prime}-f\right]$ quinoxaline (dpq) and dipyrido[3,2$\left.a: 2^{\prime}, 3^{\prime}-c\right]$ phenazine (dppz) (figure 8). ${ }^{62}$ The dppz complexes showed novel photo-induced DNA cleavage activity and significant photocytotoxicity.

The phen complexes in the absence of any photoactive ligand are poor photocleavers of plasmid supercoiled (SC) pUC19 DNA. The dpq and dppz complexes with respective photoactive quinoxaline and phenazine 


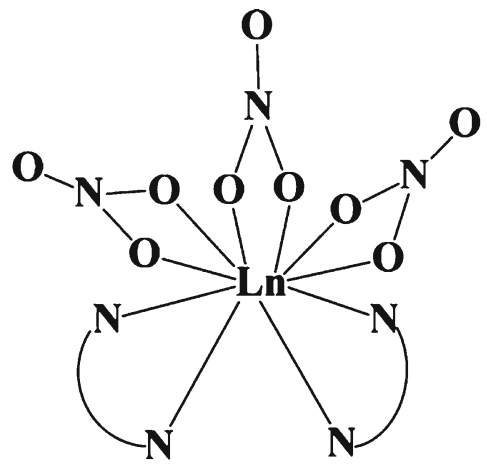

$\mathrm{Ln}=\mathrm{La}(\mathrm{III})$ and $\mathrm{Gd}(\mathrm{III})$

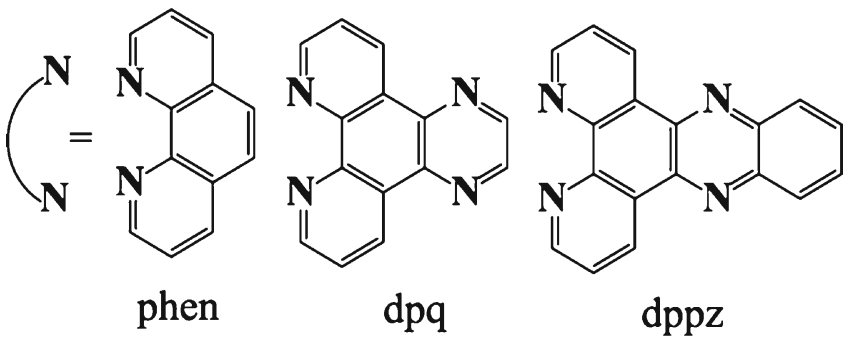

Figure 8. $\mathrm{La}(\mathrm{III})$ and $\mathrm{Gd}(\mathrm{III})$ complexes of phenanthroline bases.

moiety showed significant photo-induced DNA cleavage activity at a nanomolar complex concentration. The dppz complexes showed $\sim 90 \%$ cleavage of SC DNA to its nicked circular (NC) form at a complex concentration of $0.8 \mu \mathrm{M}$ on irradiation with UV-A light of $365 \mathrm{~nm}$ for $2 \mathrm{~h}$, while the dpq complexes showed $\sim 85 \%$ cleavage of SC DNA under similar conditions. The complexes were not cleavage active in dark thereby contrasting to the well-known hydrolytic DNA cleavage activity shown by the lanthanides. ${ }^{70,71}$ The DNA groove binding studies using minor groove binder distamycinA and the major groove binder methyl green suggested minor and major groove binding preferences of the dpq and dppz complexes, respectively. ${ }^{72,73}$ Mechanistic investigations using various singlet oxygen quenchers and hydroxyl radical scavengers suggested involvement of both singlet oxygen $\left({ }^{1} \mathrm{O}_{2}\right)$ and hydroxyl radicals $\left(\mathrm{HO}^{\bullet}\right)$ in the DNA photocleavage reactions. ${ }^{62,74}$

To test the photoactivated anticancer activity of these dppz complexes, the photocytotoxicity experiments were carried out in human cervical carcinoma (HeLa) cells using MTT (3-(4,5-dimethylthiazol-2yl)-2,5-diphenyltetrazolium bromide) assay. The dppz complexes $\left[\mathrm{La}(\mathrm{dppz})_{2}\left(\mathrm{NO}_{3}\right)_{3}\right]$ and $\left[\mathrm{Gd}(\mathrm{dppz})_{2}\left(\mathrm{NO}_{3}\right)_{3}\right]$ upon prior incubation for $4 \mathrm{~h}$ in dark and subsequent photo-exposure to UV-A light $(365 \mathrm{~nm})$ for $15 \mathrm{~min}$ showed a dose-dependent decrease in cell viability with $\mathrm{IC}_{50}$ values of $0.34 \mu \mathrm{M}$ and $0.57 \mu \mathrm{M}$, respectively. The cells unexposed to light gave an $\mathrm{IC}_{50}$ value of $>100 \mu \mathrm{M}$ for both the complexes. Interestingly, the dppz ligand alone showed significant dark toxicity $\left(\mathrm{IC}_{50}=11.6 \mu \mathrm{M}\right)$ upon incubation for $24 \mathrm{~h}$ in dark and photocytotoxicity in UV-A light of $365 \mathrm{~nm}$ $\left(\mathrm{IC}_{50}=0.41 \mu \mathrm{M}\right)$ upon $4 \mathrm{~h}$ incubation in dark followed by photo-irradiation. Cisplatin, as a standard control for assessing the dark toxicity, gave an $\mathrm{IC}_{50}$ value of $7.5 \mu \mathrm{M}$ in HeLa cells on $24 \mathrm{~h}$ incubation. A $4 \mathrm{~h}$ incubation of the HeLa cells with cisplatin in dark followed by photoexposure to UV-A light gave $\mathrm{IC}_{50}$ values of $71.3 \mu \mathrm{M}$ in dark and $68.7 \mu \mathrm{M}$ in UV-A light. ${ }^{62}$ Photofrin is known to have an $\mathrm{IC}_{50}$ value of $4.3 \pm 0.2 \mu \mathrm{M}$ on $633 \mathrm{~nm}$ excitation $\left(5 \mathrm{~J} \mathrm{~cm}^{-2}\right)$ and $>41 \mu \mathrm{M}$ in dark in HeLa cells. ${ }^{75}$ To explore the role of the lanthanide ions, a zinc(II) dppz complex $\left[\mathrm{Zn}(\mathrm{dppz})_{2}\left(\mathrm{NO}_{3}\right)_{2}\right]$ as a control gave an $\mathrm{IC}_{50}$ value of $0.37 \mu \mathrm{M}$ in UV-A light in HeLa cells, while upon $24 \mathrm{~h}$ incubation in dark it gave an $\mathrm{IC}_{50}$ value of $22.4 \mu \mathrm{M}$ indicating significant dark toxicity of the complex. ${ }^{62}$ In contrast, there was significant reduction in the dppz ligand dark toxicity on binding to the lanthanide(III) ions while retaining the photocytotoxic activity in the UV-A light of $365 \mathrm{~nm}$. Control experiments on HeLa cells exposed to the UVA light under similar conditions, but in the absence of any added complex, showed no significant effect on the cell viability indicating the fact that cellular damage is being caused by the complexes in the presence of UV-A light.

As discussed above, $\mathrm{La}(\mathrm{III})$ and $\mathrm{Gd}(\mathrm{III})$ complexes of phenanthroline bases (L), viz., $\left[\mathrm{Ln}(\mathrm{L})_{2}\left(\mathrm{NO}_{3}\right)_{3}\right]$ were found to show photo-induced DNA cleavage activity and the dppz complexes were found to be photocytotoxic toward HeLa cells in UV-A light. The complexes, however, showed structural changes on dissolution due to dissociation of one nitrate ligand. Besides, the bis complexes having two dppz ligands in a cis disposition are likely to make these complexes structurally unfavourable towards effective binding to duplex DNA. To ensure better solution stability and DNA binding efficacy of the complexes while retaining similar photocytotoxicity as observed for the bis-dppz complexes, the nitrate anions were replaced by an acetylacetonate anion (acac). The presence of three bidentate acac ligands allows coordination of only one phenanthroline base to the $\operatorname{Ln}($ III) instead of two such bases due to larger bite of the acac ligand when compared to the nitrate ligand. The strong complexing ability of the $O, O$-donor acac ligand is attributed to the formation of a six-membered chelate ring when acac ligand binds to the relatively large and oxophilic Ln(III) cation (figure 9). In contrast, complexation of the $O, O$-donor nitrate ligand results in the formation of a four-membered 


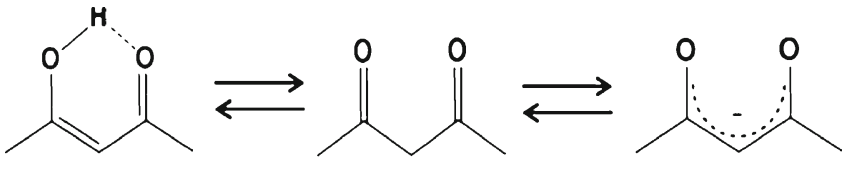

Acetylacetone (Hacac); $\mathrm{p} K_{\mathrm{a}} \sim 8.9$

Figure 9. Resonance structures of the acetylacetone ligand.

chelate ring. Complexes reported were of formulations $\left[\mathrm{La}(\mathrm{L})(\mathrm{acac})_{3}\right]$ and $\left[\mathrm{Gd}(\mathrm{L})(\mathrm{acac})_{3}\right]$ (L is phen, dpq or dppz) showing photo-induced DNA cleavage activity and cytotoxicity (figure 10). ${ }^{63}$

The phen complexes were not efficient photocleavers of DNA in the absence of any photoactive moiety in these complexes. The dppz complexes on photo-irradiation at $365 \mathrm{~nm}$ for $2 \mathrm{~h}$ showed $\sim 85 \%$ cleavage of SC DNA to its $\mathrm{NC}$ form at a complex concentration of $2 \mu \mathrm{M}$ (dpq complexes: $\sim 77 \%$ cleavage). The complexes did not show any DNA cleavage activity in dark thus ruling out any possibility of hydrolytic DNA damage. The mechanistic data suggested minor and major groove binding preferences for the dpq and dppz complexes, respectively. Singlet oxygen and hydroxyl radicals were found to be the ROS in the photocleavage reactions. Photocytotoxicity of the dppz complexes were studied in HeLa cells by MTT assay. The complexes upon prior incubation for $4 \mathrm{~h}$ in dark and subsequent photoexposure to UV-A light of $365 \mathrm{~nm}$ for $15 \mathrm{~min}$ showed a dose-dependent decrease in the cell viability giving an $\mathrm{IC}_{50}$ value of $0.46( \pm 0.05) \mu \mathrm{M}$ for $\left[\mathrm{La}(\mathrm{dppz})(\mathrm{acac})_{3}\right]$ and $0.53( \pm 0.03) \mu \mathrm{M}$ for $\left[\mathrm{Gd}(\mathrm{dppz})(\mathrm{acac})_{3}\right]$. The cells

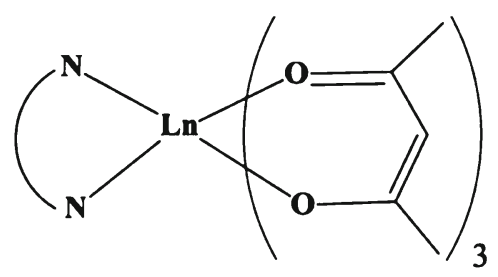

$\mathrm{Ln}=\mathrm{La}(\mathrm{III})$ and $\mathrm{Gd}(\mathrm{III})$
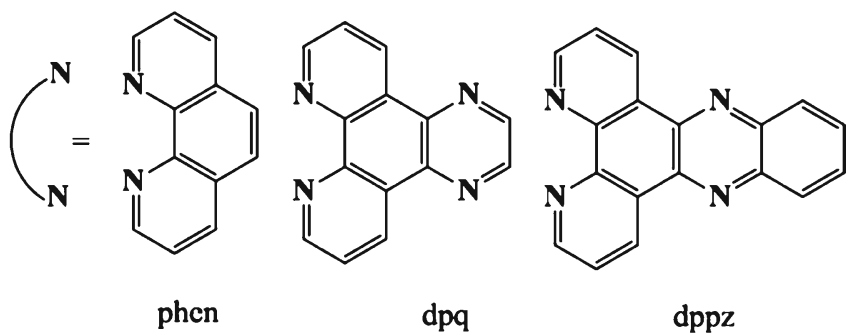

Figure 10. $\mathrm{La}(\mathrm{III})$ and $\mathrm{Gd}(\mathrm{III})$ complexes of phenanthroline bases and acetylacetonate ligand. unexposed to light gave an $\mathrm{IC}_{50}$ value $>100 \mu \mathrm{M}$ indicating negligible dark toxicity of the complexes. No significant reduction in the cell viability was observed upon incubation of the cells with the complex in dark for $24 \mathrm{~h}^{6}{ }^{63}$ The binding of the lanthanide(III) ion to the dppz base is found to significantly decrease the dark toxicity of the dppz ligand, while retaining its photocytotoxicity. Interestingly, the PDT effect of the mono-dppz complexes is similar to that of the bis-dppz complexes of Ln(III). The presence of a single dppz base seems to be adequate for exerting high photocytotoxic effect in this class of $\mathrm{Ln}(\mathrm{III})$ complexes. Similarly, Chen and co-workers studied two structurally characterized $\mathrm{Eu}(\mathrm{III})$ complexes of dpq and dppz, viz., $\left[\mathrm{Eu}(\mathrm{dpq})(\mathrm{acac})_{3}\right]$ and $\left[\mathrm{Eu}(\mathrm{dppz})(\mathrm{acac})_{3}\right]$ for their photoactivated DNA cleavage activity and cytotoxicity in UV-A and natural light. ${ }^{66}$ The complexes were found to photocleave DNA in UV-A as well as natural light by dual mechanistic pathways involving the formation of both singlet oxygen and hydroxyl radicals as ROS. However, the complexes were found to be much less active in natural light compared to the UV-A light. Photocytotoxicity assay showed that the complexes are cytotoxic to HeLa cells upon irradiation with natural light giving $\mathrm{IC}_{50}$ value of $19.11( \pm 3.56) \mu \mathrm{M}$ for the dpq complex and $17.95( \pm 5.47) \mu \mathrm{M}$ for the dppz complex. The cell death mechanism was found to be apoptotic rather than necrotic as assessed from Hoechst staining of the HeLa cells treated with the complex and photo-irradiated. ${ }^{66}$

To augment the photocytotoxicity of the complexes, lanthanide complexes of modified phenanthroline bases are reported by incorporating an additional pyridyl arm to the phen base. This pyridyl moiety is likely to extend the $\pi$ conjugation of the resulting phenanthroline bases (pyL) and may result in an enhanced photosensitizing ability. The presence of a polypyridyl ligand in the complex is expected to reduce the undesirable hydrolytic DNA cleavage activity since lanthanides are well-known to display hydrolytic DNA cleavage activity. ${ }^{70,71}$ Complexes [Ln(pyphen)(acac) $\left.)_{2}\left(\mathrm{NO}_{3}\right)\right]$, [Ln(pydppz) $\left.(\text { acac })_{2}\left(\mathrm{NO}_{3}\right)\right]$ and $\left[\mathrm{La}(\right.$ pydppz $\left.)(\text { anacac })_{2}\left(\mathrm{NO}_{3}\right)\right]$ were reported to show significant DNA photocleavage activity and photocytotoxicity in HeLa cells (figure 11). ${ }^{64}$ Complex $\left[\mathrm{La}(\text { pydppz)(anacac })_{2}\left(\mathrm{NO}_{3}\right)\right]$ with an acac having a pendant anthracenyl moiety as a fluorophore was used to study the cellular localization of the complex by confocal fluorescence microscopy. The pydppz complexes were found to show essentially complete cleavage of SC DNA to its NC form at a low complex concentration of $1.0 \mu \mathrm{M}$ for an exposure time of $2 \mathrm{~h}$. Complex $\left[\mathrm{La}(\right.$ pydppz $\left.)(\text { anacac })_{2}\left(\mathrm{NO}_{3}\right)\right]$ having an anthracenyl 


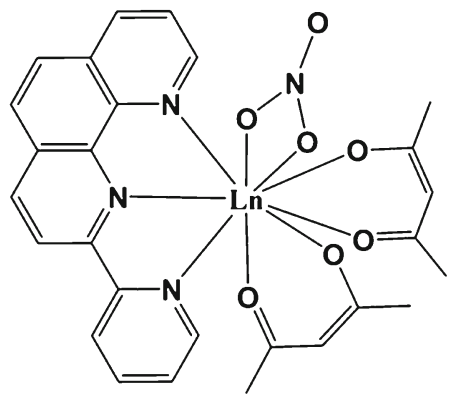

$\mathrm{Ln}=\mathrm{La}(\mathrm{III})$ and $\mathrm{Gd}(\mathrm{III})$

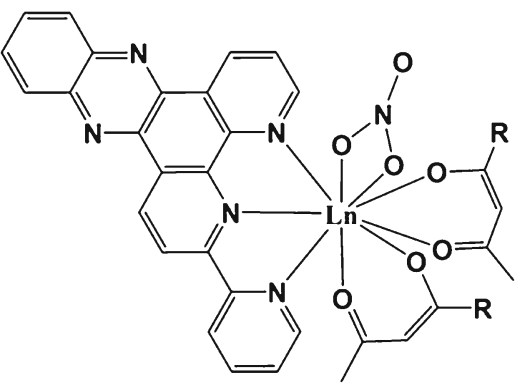

$\mathrm{R}=\mathrm{Me}, \mathrm{Ln}=\mathrm{La}(\mathrm{III})$ and $\mathrm{Gd}(\mathrm{III})$

$\mathrm{R}=$ anthracenyl and $\mathrm{Ln}=\mathrm{La}(\mathrm{III})$

Figure 11. $\mathrm{La}(\mathrm{III})$ and $\mathrm{Gd}(\mathrm{III})$ complexes of pyridylphenanthroline bases.

moiety showed even better DNA photocleavage activity compared to its acetylacetonate (acac) analogues which was attributed to the presence of two anthracenyl moieties imparting additional photosensitizing ability to the complex. The pydppz complexes were found to bind through the major groove of DNA while the pyphen complexes preferred minor groove binding. The photocleavage reactions showed formation of both singlet oxygen and hydroxyl radicals as observed for the other lanthanide complexes. ${ }^{64}$ The MTT assay of the pyphen complexes using HeLa cancer cells, upon prior incubation for $4 \mathrm{~h}$ in the dark and subsequent photoexposure to UV-A light of $365 \mathrm{~nm}$ for $15 \mathrm{~min}$, showed moderate decrease in the cell viability giving $\mathrm{IC}_{50}$ values of $16.4( \pm 1.5)$ for [La(pyphen $\left.)(\mathrm{acac})_{2}\left(\mathrm{NO}_{3}\right)\right]$ and $18.4( \pm 1.8) \mu \mathrm{M}$ for $\left[\mathrm{Gd}(\right.$ pyphen $\left.)(\mathrm{acac})_{2}\left(\mathrm{NO}_{3}\right)\right]$ in light and 30.8 $( \pm 2.0)$ for [La(pyphen $\left.)(\mathrm{acac})_{2}\left(\mathrm{NO}_{3}\right)\right]$ and $33.9( \pm 2.2) \mu \mathrm{M}$ for $\left[\mathrm{Gd}(\right.$ pyphen $\left.)(\mathrm{acac})_{2}\left(\mathrm{NO}_{3}\right)\right]$ in dark. The pydppz complexes showed a dosedependent decrease in cell viability with $\mathrm{IC}_{50}$ values of $0.16( \pm 0.01), 0.15( \pm 0.01)$ and $0.26( \pm 0.02) \mu \mathrm{M}$ for $\left[\mathrm{La}(\right.$ pydppz $\left.)(\mathrm{acac})_{2}\left(\mathrm{NO}_{3}\right)\right],\left[\mathrm{Gd}(\mathrm{pydppz})(\mathrm{acac})_{2}\left(\mathrm{NO}_{3}\right)\right]$ and $\left[\mathrm{La}(\right.$ pydppz $\left.)(\text { anacac })_{2}\left(\mathrm{NO}_{3}\right)\right]$, respectively, in UVA light, while the cells unexposed to light gave an $\mathrm{IC}_{50}$ value of $>3 \mu \mathrm{M}$. The insufficient solubility of the pydppz complexes limited the use of complex concentration beyond $3 \mu \mathrm{M}$. The binding of pydppz to the lanthanide ions significantly improved its aqueous solubility thus making the MTT assay possible for the complexes using standard protocols up to a concentration of $3.0 \mu \mathrm{M}$. The MTT assay data showed that the lanthanide-pydppz complexes are more cytotoxic in light compared to their dppz analogues. High photocytotoxicity at nanomolar concentration makes these complexes potential agents for photochemotherapeutic applications in blue light. ${ }^{64}$

Acridine orange/ethidium bromide (AO/EB) dual staining of the HeLa cells treated with
$\left[\mathrm{Gd}\left(\right.\right.$ pydppz) $\left.(\mathrm{acac})_{2}\left(\mathrm{NO}_{3}\right)\right]$ gave insight into the mechanism of cell death by looking at the changes in the nuclear morphology upon PDT. The cells treated with the complex in dark did not show any significant nuclear morphological change. But the cells treated with the complex and light showed significant increase in the apoptotic nuclear morphology wherein the nuclei had condensed significantly and had intense EB staining. The nuclei of cells treated in the dark and also of the untreated cells remained intact and stain evenly with AO but not with EB. The mechanistic aspects of cell death were also studied by flow cytometric analysis using $\left[\mathrm{Gd}(\mathrm{pydppz})(\mathrm{acac})_{2}\left(\mathrm{NO}_{3}\right)\right]$ that showed significant activity with respect to its photocytotoxic property in light. ${ }^{64}$ Cells treated with the complex in dark were exposed to UV-A light of $365 \mathrm{~nm}$ and then stained with propidium iodide (PI) to check for fragmented DNA which is indicated by an increase in the sub-G1/G0 population. It was observed that a concentration of $0.15 \mu \mathrm{M}$ of the complex induced significant apoptosis in $24 \mathrm{~h}$ and the extent of apoptosis increased on increasing the complex concentration. No significant induction of apoptosis by the complex was observed in dark suggesting that the non-toxic nature of the complex in dark and highly photocytotoxic behaviour upon photoactivation. To study the cellular uptake and localization behaviour of the complexes in HeLa cancer cells, fluorescent complex $\left[\mathrm{La}(\mathrm{pydppz})(\text { anacac })_{2}\left(\mathrm{NO}_{3}\right)\right]$ was used for confocal microscopic studies using $5 \mu \mathrm{M}$ solution of the complex with PI as a nuclear staining agent. The confocal images taken after $1 \mathrm{~h}$ of incubation showed rapid internalization and accumulation of the complex inside the nuclei of the cells. The complex remained largely inside the nucleus even after $2 \mathrm{~h}$ of incubation but a small transfer of fluorescence from the nucleus to the cytoplasm was observed. The images taken after $4 \mathrm{~h}$ showed egress of the complex from the nucleus and significant accumulation in the cytosol. No change in 
the nuclear morphology was evidenced indicating that the complex remained innocuous within the cell unless photoactivated. ${ }^{64}$ This type of uptake/egress phenomena is known for similar lanthanide complexes. ${ }^{62}$ The results showing nuclear localization of the potent PDT agent are novel considering that these complexes could serve the dual purpose of detecting the tumour while remaining harmless inside the cell and damaging the DNA only upon photoactivation leading to apoptosis. The lanthanide-based MRI agents are known to be useful for only tumour detection but not for its selective damage.

3.3b Photoactive complexes of terpyridine bases: Transition metal complexes of terpyridine (tpy) and its derivatives (R-tpy) form an important class in coordination chemistry showing interesting structural, physicochemical and biochemical properties. ${ }^{76-81}$ The tridentate terpyridine moiety can be readily derivatized by a variety of substituents at the $4^{\prime}$ position and the substituted terpyridines are excellent ligands in coordination chemistry (figure 12) ${ }^{76}$ Lanthanide(III) complexes of terpyridine and substituted terpyridine ligands are known for various applications. ${ }^{82-86}$ The rich photophysical properties of the substituted terpyridine derivatives and their metal complexes make them suitable for various photobiological applications. ${ }^{76-81,87,88}$

As discussed above, the $\mathrm{La}(\mathrm{III})$ and $\mathrm{Gd}(\mathrm{III})$ complexes of dipyridophenazine (dppz) and pyridyldipyridophenazine (py-dppz) are efficient DNA photocleaving and photocytotoxic agents in UV-A light. To explore this chemistry further, a new series of lanthanide complexes having pyrene-appended terpyridine and acetylacetonates as ligands are reported with an aim to enhance the photocytotoxicity of the complexes. ${ }^{65}$ The pyrenyl terpyridine (py-tpy) ligand has tpy with a pendant pyrenyl moiety which could serve as a photosensitizer-cum-DNA binder.

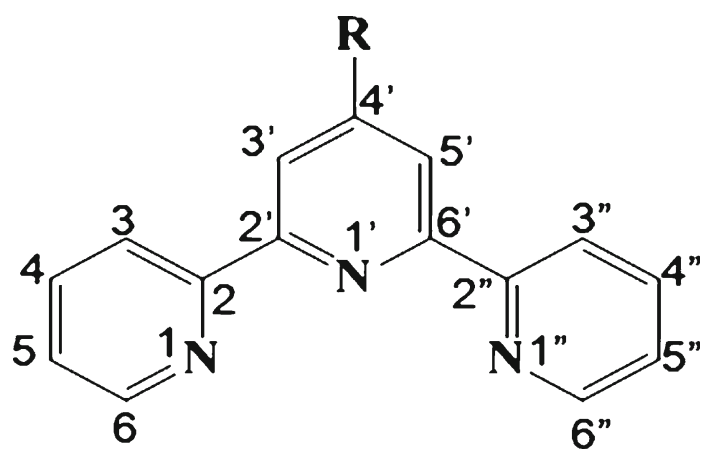

Figure 12. 4'-Substituted terpyridine base and the atom numbering scheme.
The excellent lipophilicity of the terpyridine ligands could increase the cell permeability of the complexes thereby increasing their photocytotoxicity. ${ }^{76,87}$ The photoactive pyrenyl moiety, also being a fluorophore, could be used for confocal fluorescence microscopy to study the localization of the complex within the cancer cell and to study its cytotoxicity on photoactivation. The $O, O$-donor $\beta$-diketonate ligand is used for its strong complexing nature with the oxophilic lanthanide(III) ions resulting in the formation of a stable complex. In addition, a carbohydrate-appended acetylacetonate ligand was used to increase the aqueous solubility of the complexes and to augment their targeting potential in the cancer cells considering that there is an upregulation of glycolysis and a decrease in oxidative phosphorylation in cancer cells compared to the normal cells which results in inefficiency in the metabolism of the cancer cells. The glucose requirements of cancer cells are significantly higher compared to the normal cells for their uncontrolled growth resulting in the overexpression of certain proteins (GLUTs) which are a class of transmembrane proteins mediating the transport of glucose across the membrane of the cells. ${ }^{89,90}$ The complexes were designed with the dual strategy of combining imaging with therapy. Lanthanide(III) complexes [ $\left.\mathrm{Ln}(\mathrm{R}-\mathrm{tpy})(\mathrm{acac})\left(\mathrm{NO}_{3}\right)_{2}\right]$ and $\left[\mathrm{Ln}\right.$ (py-tpy)(sacac) $\left.\left(\mathrm{NO}_{3}\right)_{2}\right]$, where $\mathrm{Ln}=\mathrm{La}(\mathrm{III})$ and $\mathrm{Gd}(\mathrm{III}), \mathrm{R}$-tpy is $4^{\prime}$-phenyl-2,2':6', $2^{\prime \prime}$-terpyridine (phtpy), 4'-(1-pyrenyl)-2,2':6', $2^{\prime \prime}$-terpyridine (py-tpy), acac is acetylacetonate and sacac is 4-hydroxy-6- $\{4-[(\beta-$ D-glucopyranoside)oxy]phenyl $\}$ hex-3,5-dien-2-onate, were reported to show significant DNA photocleavage activity and photocytotoxicity (figure 13). ${ }^{65}$

The UV-A light induced DNA photocleavage data for the py-tpy complexes showed essentially complete cleavage of SC DNA to its NC form at a complex concentration of $2.0 \mu \mathrm{M}$ for an exposure time of $1 \mathrm{~h}$. The ph-tpy complexes did not show any significant DNA photocleavage activity. The mechanistic studies revealed the formation of singlet oxygen and hydroxyl radicals as the cleavage active species. ${ }^{65}$ Photoactivated anticancer activity of the complexes was tested by MTT assay in human cervical cancer (HeLa) cells. The ph-tpy complexes upon prior incubation for $4 \mathrm{~h}$ in the dark and subsequent photo-exposure to UV-A light of $365 \mathrm{~nm}$ for $15 \mathrm{~min}$ showed only moderate decrease in the cell viability giving $\mathrm{IC}_{50}$ value of $37.8( \pm 4.0) \mu \mathrm{M}$ for $\left[\mathrm{La}(\right.$ ph-tpy $\left.)(\mathrm{acac})\left(\mathrm{NO}_{3}\right)_{2}\right]$ and $25.0( \pm 2.0) \mu \mathrm{M}$ for $\left[\mathrm{Gd}(\right.$ ph-tpy $)($ acac $\left.)\left(\mathrm{NO}_{3}\right)_{2}\right]$ in UV-A light and $>200 \mu \mathrm{M}$ for both in dark. The py-tpy complexes [La(pytpy)(acac) $\left.\left(\mathrm{NO}_{3}\right)_{2}\right]$, [La(py-tpy)( $\left.\left.\mathrm{sacac}\right)\left(\mathrm{NO}_{3}\right)_{2}\right],[\mathrm{Gd}(\mathrm{py}-$ tpy)(acac) $\left.\left(\mathrm{NO}_{3}\right)_{2}\right]$ and $\left[\mathrm{Gd}(\right.$ py-tpy $\left.)(\mathrm{sacac})\left(\mathrm{NO}_{3}\right)_{2}\right]$ showed a dose-dependent decrease in the cell 

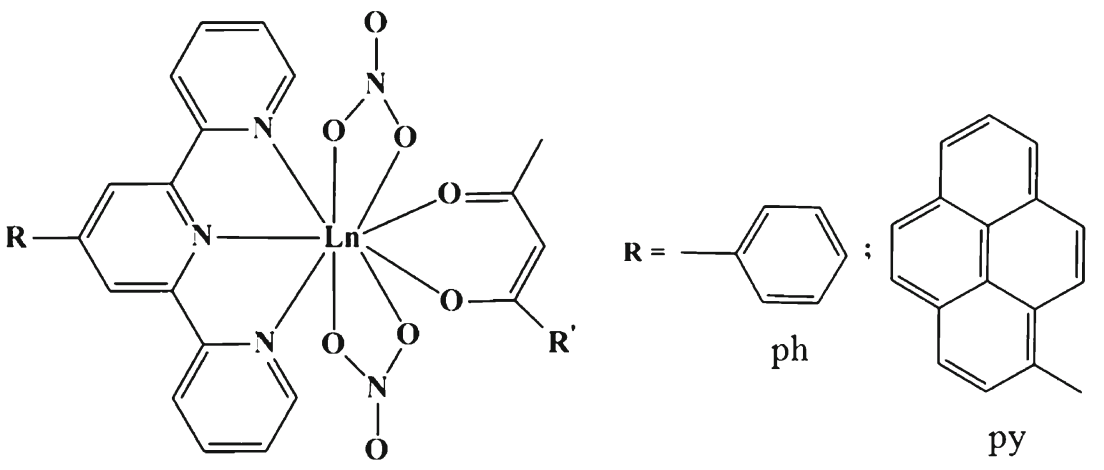

$\mathrm{Ln}=\mathrm{La}(\mathrm{III})$ and $\mathrm{Gd}(\mathrm{III})$

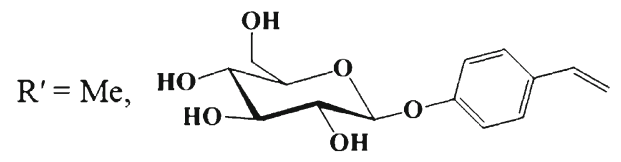

Figure 13. $\mathrm{La}(\mathrm{III})$ and $\mathrm{Gd}(\mathrm{III})$ complexes of $4^{\prime}$-substituted terpyridine bases of acetylacetonate and carbohydrate appended acetylacetonate ligands.

viability giving respective $\mathrm{IC}_{50}$ values of $0.04( \pm 0.01)$, $0.03( \pm 0.01), 0.05( \pm 0.01)$ and $0.03( \pm 0.01) \mu \mathrm{M}$ in UVA light of $365 \mathrm{~nm}$. The pyrenyl ligand was found to be less toxic compared to its $\mathrm{Ln}$ (III) complexes giving an $\mathrm{IC}_{50}$ value of $0.07( \pm 0.01) \mu \mathrm{M}$ in light while being non-toxic in dark. The cells unexposed to light gave an $\mathrm{IC}_{50}$ value of $>200 \mu \mathrm{M}$ for all the complexes. ${ }^{65}$ The complexes are thus non-toxic in dark but become highly cytotoxic upon irradiation with UV-A light of $365 \mathrm{~nm}$. A facile intersystem crossing (ISC) mediated by the heavy lanthanides is likely to result in the efficient generation of singlet oxygen compared to the py-tpy ligand alone. ${ }^{91,92}$ No significant difference in the $\mathrm{IC}_{50}$ values in light was observed between the pyrenyl complexes of acac and carbohydrate appended acac ligands upon $4 \mathrm{~h}$ incubation of the complexes in dark followed by photo-exposure. To get a deeper insight into the cellular uptake behaviour of the complexes, time dependent photocytotoxicity studies were done using $\left[\mathrm{La}\right.$ (py-tpy)(acac) $\left.\left(\mathrm{NO}_{3}\right)_{2}\right]$ having no pendant glucose moiety and $\left[\mathrm{La}(\right.$ py-tpy $)($ sacac $\left.)\left(\mathrm{NO}_{3}\right)_{2}\right]$ having a pendant glucose moiety. Incubation of either complex for $1 \mathrm{~h}$ in dark followed by photoexposure gave an $\mathrm{IC}_{50}$ value of $0.08( \pm 0.01) \mu \mathrm{M}$ for [La(py-tpy) $(\mathrm{acac})\left(\mathrm{NO}_{3}\right)_{2}$ ] and $0.04( \pm 0.01) \mu \mathrm{M}$ for $\left[\mathrm{La}\right.$ (py-tpy) $($ sacac $\left.)\left(\mathrm{NO}_{3}\right)_{2}\right]$. The corresponding $\mathrm{IC}_{50}$ values for $2 \mathrm{~h}$ incubation of the complexes in dark followed by exposure to light were $0.05( \pm 0.01) \mu \mathrm{M}$ and $0.03( \pm 0.01) \mu \mathrm{M}$. A clear difference in the $\mathrm{IC}_{50}$ values of the complexes was observed for $2 \mathrm{~h}$ incubation time. The photocytoxicity of the complexes was, however, very similar when incubation time was $4 \mathrm{~h}$ prior to irradiation. The results suggest two different uptake pathways for the complexes. The acac complexes being more lipophilic could have a passive diffusion uptake process, while the complexes having pendant carbohydrate moiety could be taken up by the cells through a receptor mediated endocytic pathway. Despite lower lipophilicity in the presence of carbohydrate moiety in sacac, the over-expressed glucose transporters (GLUTs) in HeLa cells could be responsible for the endocytosis of the sacac complex. The MTT assay data showed that the py-tpy complexes are more photocytotoxic compared to their ph-tpy or dppz analogues, possibly due to greater photosensitizing ability of the py-tpy ligand.

The photocytotoxicity of the lanthanide(III) complexes is of importance as complex trans$\left[\mathrm{Pt}\left(\mathrm{N}_{3}\right)_{2}(\mathrm{OH})_{2}\left(\mathrm{NH}_{3}\right)(\mathrm{py})\right]$, reported by Sadler and co-workers, is known to give an $\mathrm{IC}_{50}$ value of $6.1( \pm 0.5) \mu \mathrm{M}$ in UV-A light of $365 \mathrm{~nm}\left(5 \mathrm{~J} \mathrm{~cm}^{-2}\right.$ power) and $>244.3 \mu \mathrm{M}$ in dark in $\mathrm{HaCaT}$ cancer cells. ${ }^{93}$ Lanthanide complexes of the py-tpy ligand are thus remarkably photocytotoxic in UV-A light of $365 \mathrm{~nm}$ at nanomolar concentration while remaining essentially non-toxic in dark. The AO/EB dual staining of the HeLa cells treated with the complexes [La(pytpy)(acac) $\left.\left(\mathrm{NO}_{3}\right)_{2}\right]$ and $\left[\mathrm{La}(\right.$ py-tpy $)($ sacac $\left.)\left(\mathrm{NO}_{3}\right)_{2}\right]$ and subsequently photo-irradiated with UV-A light of $365 \mathrm{~nm}$ showed significant nuclear morphological changes with membrane blebbing which is characteristic of early apoptosis. The nuclei of the cells treated in dark and also of the untreated cells were found to remain intact and stained evenly with $\mathrm{AO}$ but not with EB. The confocal imaging studies on 
HeLa cells using fluorescent py-tpy complexes [La(pytpy)(acac) $\left.\left(\mathrm{NO}_{3}\right)_{2}\right]$ and $\left[\mathrm{La}\left(\right.\right.$ py-tpy)$($ sacac $\left.)\left(\mathrm{NO}_{3}\right)_{2}\right]$ were reported to study the cellular uptake and localization. Complex $\left[\mathrm{La}\right.$ (py-tpy)(sacac) $\left.\left(\mathrm{NO}_{3}\right)_{2}\right]$ having a pendant glucose moiety was used for the confocal study to explore the effect of the carbohydrate moiety on the cellular uptake behaviour since GLUT receptors are known to overexpress in a majority of cancer cells and isolated cancer cell lines. The confocal images were taken after $15 \mathrm{~min}, 30 \mathrm{~min}, 1 \mathrm{~h}$ and $4 \mathrm{~h}$ of incubation of the complexes to measure their time dependent cellular uptake and localization. The images taken after $15 \mathrm{~min}$ showed little uptake of both the complexes. Images taken after $30 \mathrm{~min}$ showed no significant enhancement in the fluorescent intensity for both the complexes. Interestingly, images of the cells treated with the glucose bearing complex [La(py-tpy)(sacac) $\left.\left(\mathrm{NO}_{3}\right)_{2}\right]$ collected after $1 \mathrm{~h}$ showed significant enhancement in the intensity having diffused cytosolic distribution with punctate staining of the cells around the perinuclear region. The images were found to be much less intense in case of glucose-free complex [La(pytpy)(acac) $\left.\left(\mathrm{NO}_{3}\right)_{2}\right]$. The confocal images of the cells after $4 \mathrm{~h}$ incubation showed similar intensity for both the complexes. The intracellular localization of the complex $\left[\mathrm{La}\left(\right.\right.$ py-tpy) $\left.(\mathrm{acac})\left(\mathrm{NO}_{3}\right)_{2}\right]$ showed a diffused staining of the whole cytoplasm. The nuclei gave negligible or no emission, indicating insignificant nuclear uptake in both the cases. The results suggest two possible uptake pathways with the glucose-free complex taken up by a diffusion process and glucose-bearing complex internalized by receptor mediated endocytosis (RME). ${ }^{94}$ No change in nuclear morphology was observed in the confocal images of the cells indicating that the complexes remain harmless in dark but become potentially cytotoxic upon photoexposure. The results are of interest considering that the lanthanide(III) complexes could serve the dual purpose of detecting the tumour while remaining harmless inside the cell and damaging the cell upon photo-activation leading to apoptosis.

\section{A comparison of the activity of the lanthanide complexes}

A comparison of the DNA photocleavage activity, photocytotoxicity and cellular localization behaviour of the lanthanide(III) complexes is made below.

\subsection{DNA Photocleavage}

The UV-A $(365 \mathrm{~nm}, 6 \mathrm{~W}$ power $)$ light-induced DNA cleavage activity of the bis-dppz complexes, viz., $\left[\mathrm{La}(\mathrm{dppz})_{2}\left(\mathrm{NO}_{3}\right)_{3}\right]$ and $\left[\mathrm{Gd}(\mathrm{dppz})_{2}\left(\mathrm{NO}_{3}\right)_{3}\right]$ is more pronounced than the mono-dppz complexes $\left[\mathrm{La}(\mathrm{dppz})(\mathrm{acac})_{3}\right]$ and $\left[\mathrm{Gd}(\mathrm{dppz})(\mathrm{acac})_{3}\right]$, despite their very similar DNA binding affinities. This could be due to the presence of two photoactive dppz bases in the bis complexes imparting additional photosensitizing ability as compared to the single dppz base complexes. Attachment of an additional pyridyl group to the dppz ligand enhances the DNA photocleavage activity as evidenced for the pydppz complexes, viz. $\left[\mathrm{La}(\right.$ pydppz $\left.)(\mathrm{acac})_{2}\left(\mathrm{NO}_{3}\right)\right],\left[\mathrm{Gd}(\mathrm{pydppz})(\mathrm{acac})_{2}\left(\mathrm{NO}_{3}\right)\right]$ and $\left[\mathrm{La}(\right.$ pydppz $\left.)(\text { anacac })_{2}\left(\mathrm{NO}_{3}\right)\right]$. The pyridyl group increases the overall planarity of the dppz ligand and enhances its photosensitizing ability compared to dppz. ${ }^{64}$ The presence of an additional photoactive anthracenyl moiety in the complex $\left[\mathrm{La}(\right.$ pydppz $\left.)(\text { anacac })_{2}\left(\mathrm{NO}_{3}\right)\right]$ makes it a better photocleaver of DNA in UV-A light compared to its anthracene free analogues. The pyrenyl terpyridine (py-tpy) complexes, viz., [La(py-tpy)(acac) $\left.\left(\mathrm{NO}_{3}\right)_{2}\right]$, [La(py-tpy)(sacac) $\left.\left(\mathrm{NO}_{3}\right)_{2}\right], \quad\left[\mathrm{Gd}(\right.$ py-tpy $\left.)(\mathrm{acac})\left(\mathrm{NO}_{3}\right)_{2}\right]$ and $\left[\mathrm{Gd}(\right.$ py-tpy $\left.)(\mathrm{sacac})\left(\mathrm{NO}_{3}\right)_{2}\right]$ are better DNA photocleavers in UV-A light compared to the dppz and pydppz complexes indicating py-tpy a better photosensitizer than dppz or pydppz. The presence of an appended glucose moiety makes the complexes [La(pytpy)(sacac) $\left.\left(\mathrm{NO}_{3}\right)_{2}\right]$ and $\left[\mathrm{Gd}(\right.$ py-tpy $)($ sacac $\left.)\left(\mathrm{NO}_{3}\right)_{2}\right]$ less cleavage active compared to their glucose-free analogues. The py-tpy complexes show better aqueous

Table 1. A comparison of the DNA photocleavage activity of selected lanthanide complexes in UV-A light of $365 \mathrm{~nm}$.

\begin{tabular}{lccc}
\hline Complex & {$[$ Complex $] / \mu \mathrm{M}$} & $t / \mathrm{h}^{\mathrm{a}}$ & $\% \mathrm{NC}^{\mathrm{b}}$ \\
\hline$\left[\mathrm{Gd}(\mathrm{dppz})_{2}\left(\mathrm{NO}_{3}\right)_{3}\right]$ & 0.8 & 2 & 91 \\
{$\left[\mathrm{Gd}(\mathrm{dppz})(\mathrm{acac})_{3}\right]$} & 2.0 & 2 & 87 \\
{$\left[\mathrm{La}(\right.$ pydppz $\left.)(\mathrm{anacac})_{2}\left(\mathrm{NO}_{3}\right)\right]$} & 0.5 & 2 & 84 \\
{$\left[\mathrm{La}(\right.$ py-tpy $\left.)(\mathrm{acac})\left(\mathrm{NO}_{3}\right)_{2}\right]$} & 1.0 & 1 & 88 \\
\hline
\end{tabular}

${ }^{\mathrm{a}}$ Exposure time, $t .{ }^{\mathrm{b}} \mathrm{NC}$ is the nicked circular form of pUC19 DNA $(0.2 \mu \mathrm{g}, 30 \mu \mathrm{M})$ 
Table 2. A comparison of the $\mathrm{IC}_{50}$ values of selected lanthanide complexes in HeLa cells.

\begin{tabular}{lccc}
\hline Compound & $\mathrm{IC}_{50} / \mu \mathrm{M}(\text { light })^{\mathrm{a}}$ & $\mathrm{IC}_{50} / \mu \mathrm{M}($ dark $)$ & Light source \\
\hline$\left[\mathrm{La}(\mathrm{dppz})_{2}\left(\mathrm{NO}_{3}\right)_{3}\right]$ & 0.34 & $>100^{\mathrm{b}}$ & $\mathrm{UV}^{\mathrm{b}} \mathrm{A}^{\mathrm{c}}$ \\
{$\left[\mathrm{La}(\mathrm{dppz})(\mathrm{acac})_{3}\right]$} & $0.46( \pm 0.05)$ & $>100^{\mathrm{b}}$ & $\mathrm{UV}^{\mathrm{b}}$ \\
{$\left[\mathrm{La}(\right.$ pydppz $\left.)(\mathrm{acac})_{2}\left(\mathrm{NO}_{3}\right)\right]$} & $0.16( \pm 0.01)$ & $>3.0^{\mathrm{d}, \mathrm{e}}$ & $\mathrm{UV}^{\mathrm{c}} \mathrm{A}^{\mathrm{c}}$ \\
{$\left[\mathrm{La}(\right.$ py-tpy $\left.)(\mathrm{acac})\left(\mathrm{NO}_{3}\right)_{2}\right]$} & $0.04( \pm 0.01)$ & $>200^{\mathrm{e}}$ & $\mathrm{UV}^{\mathrm{c}}$ \\
\hline
\end{tabular}

${ }^{\mathrm{a}} \mathrm{IC}_{50}$ values correspond to $4 \mathrm{~h}$ incubation in dark followed by photoexposure to the light. ${ }^{\mathrm{b}} \mathrm{The} \mathrm{IC}_{50}$ values correspond to $24 \mathrm{~h}$ incubation in dark. ${ }^{\mathrm{c}} \mathrm{UV}-\mathrm{A}$ light of $365 \mathrm{~nm}\left(0.55 \mathrm{~J} \mathrm{~cm}^{-2}\right) .{ }^{\mathrm{d}}$ Complex concentration was limited to $3.0 \mu \mathrm{M}$ due to poor solubility in the buffer medium. ${ }^{\mathrm{e}} \mathrm{The} \mathrm{IC}_{50}$ values correspond to $4 \mathrm{~h}$ incubation in dark

solubility when compared to their dppz or pydppz analogues. Overall, the complexes of py-tpy ligand have superior photosensitizing properties compared to the dppz or pydppz complexes. A comparison of the DNA photocleavage activity of selected Ln(III) complexes is made in table 1 .

\subsection{Photocytotoxicity}

The photocytotoxic activity of the 1:2 and 1:1 dppz complexes, viz., $\left[\mathrm{La}(\mathrm{dppz})_{2}\left(\mathrm{NO}_{3}\right)_{3}\right],\left[\mathrm{Gd}(\mathrm{dppz})_{2}\left(\mathrm{NO}_{3}\right)_{3}\right]$ and $\left[\mathrm{La}(\mathrm{dppz})(\mathrm{acac})_{3}\right],\left[\mathrm{Gd}(\mathrm{dppz})(\mathrm{acac})_{3}\right]$, in $\mathrm{HeLa}$ cells in UV-A light of $365 \mathrm{~nm}\left(0.55 \mathrm{~J} \mathrm{~cm}^{-2}\right)$ is very similar. This could be due to better cellular uptake of the mono complexes which are neutral and hence more lipophilic compared to the monocationic bis complexes. Attachment of a pyridyl moiety to the dppz ligand is found to augment the photocytotoxicity of the resulting pydppz complexes as evidenced from the $\mathrm{IC}_{50}$ values of the pydppz complexes. The pyridyl group is likely to increase the aromaticity of the overall ligand and extends the planarity of the dppz ligand thereby making the pydppz ligand a better photosensitizer compared to dppz which is apparent from the reported crystal structure of $\left[\mathrm{Gd}(\right.$ pyphen $\left.)(\mathrm{acac})_{2}\left(\mathrm{NO}_{3}\right)\right]$ showing the planarity of the pyphen ligand. ${ }^{64}$ The pyrenyl terpyridine (py-tpy) complexes, viz., [La(py-tpy)(acac) $\left.\left(\mathrm{NO}_{3}\right)_{2}\right]$, [La(py-tpy)(sacac) $\left.\left(\mathrm{NO}_{3}\right)_{2}\right], \quad\left[\mathrm{Gd}\left(\right.\right.$ py-tpy)$($ acac $\left.)\left(\mathrm{NO}_{3}\right)_{2}\right]$ and $\left[\mathrm{Gd}(\right.$ py-tpy $\left.)(\mathrm{sacac})\left(\mathrm{NO}_{3}\right)_{2}\right]$ are more photocytotoxic in UV-A light of $365 \mathrm{~nm}$ compared to the dppz and pydppz complexes indicating better photosensitizing ability of py-tpy than dppz or pydppz. The $\mathrm{IC}_{50}$ values of the glucose appended complexes [La(pytpy)(sacac) $\left.\left(\mathrm{NO}_{3}\right)_{2}\right]$ and $\left[\mathrm{Gd}(\right.$ py-tpy $\left.)(\mathrm{sacac})\left(\mathrm{NO}_{3}\right)_{2}\right]$ are

(a) Nuclear localizaton
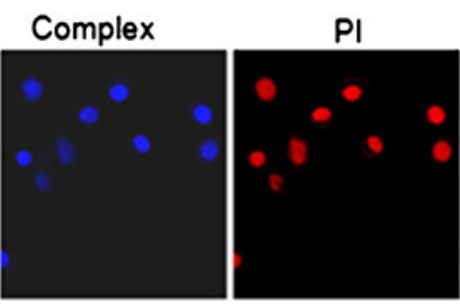

Merged
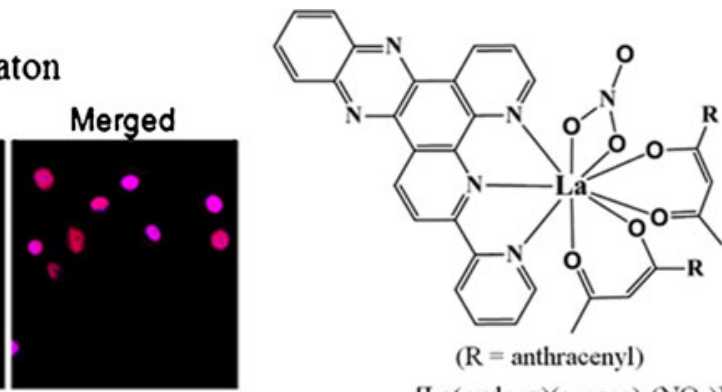

(b) Cytosolic localization

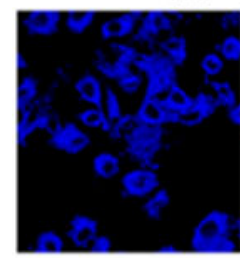

Complex

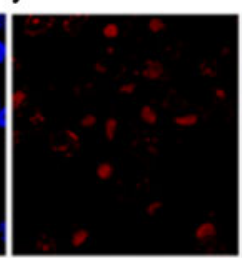

PI

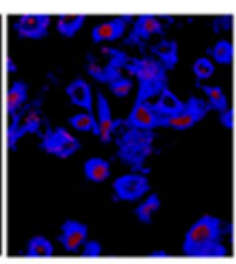

Merged
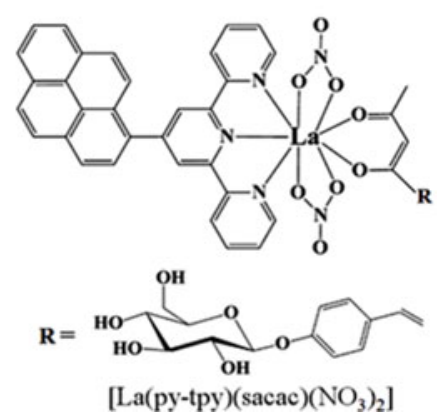

Figure 14. Confocal images of the HeLa cells showing: (a) the nuclear localization of $\left[\mathrm{La}(\mathrm{pydppz})(\text { anacac })_{2}\left(\mathrm{NO}_{3}\right)\right]$ and (b) cytosolic localization of [La(pytpy)(sacac) $\left.\left(\mathrm{NO}_{3}\right)_{2}\right]$ (incubation time, $4 \mathrm{~h}$; excitation wavelength, $365 \mathrm{~nm}$ ). 
similar to the glucose free analogues but the presence of glucose moiety improves aqueous solubility of the complex. A comparison of the photocytotoxic potential of the complexes is made in table 2 .

\subsection{Cellular localization}

Complex $\left[\mathrm{La}(\right.$ pydppz $\left.)(\text { anacac })_{2}\left(\mathrm{NO}_{3}\right)\right]$ having two pendant anthracenyl moieties showed blue emission. Confocal microscopic investigations of HeLa cells using this complex showed nuclear localization. The complex seemed to be rapidly taken up by the cells showing significant nuclear accumulation within $1 \mathrm{~h}$ incubation time. Complexes [La(py-tpy)(sacac) $\left.\left(\mathrm{NO}_{3}\right)_{2}\right]$, in contrast, showed localization primarily in the cytosol of the HeLa cells. The intracellular localization of $\left[\mathrm{La}(\right.$ py-tpy $\left.)(\mathrm{acac})\left(\mathrm{NO}_{3}\right)_{2}\right]$ did not show any granular appearance, but largely a diffused staining of the whole cytoplasm. The uptake of [ $\mathrm{La}$ (pytpy)(acac) $\left(\mathrm{NO}_{3}\right)_{2}$ ] seemed to be sluggish compared to $\left[\mathrm{La}(\right.$ pydppz $\left.)(\text { anacac })_{2}\left(\mathrm{NO}_{3}\right)\right]$ with insignificant accumulation within $1 \mathrm{~h}$ incubation time as evidenced from the fluorescence intensity of the complexes inside the HeLa cells (figure 14). ${ }^{65}$ This could be due to better lipophilicity of $\left[\mathrm{La}\left(\right.\right.$ pydppz) $\left.(\text { anacac })_{2}\left(\mathrm{NO}_{3}\right)\right]$ resulting from the presence of two pendant anthracenyl moieties compared to $\left[\mathrm{La}\right.$ (py-tpy)(acac) $\left.\left(\mathrm{NO}_{3}\right)_{2}\right]$ having the acac ligand. However, $\left[\mathrm{La}\right.$ (py-tpy) (sacac) $\left.\left(\mathrm{NO}_{3}\right)_{2}\right]$ bearing a pendant glucose moiety showed significant cytosolic distribution with punctate staining of the cells around the perinuclear region despite reduced lipophilicity (figure 14). The glucose pendant complex could be internalized by a receptor mediated process involving the overexpressed GLUTs. Overall, complexes showing nuclear localization are more attractive in PDT because they can target the nucleus of the cell and damage the DNA upon photoactivation while remaining harmless in the absence of light inside the cell.

\section{Conclusions and outlook}

This review describes the recent development in the chemistry of photoactive lanthanide complexes showing photo-induced DNA cleavage activity and photocytotoxicity for their potential applications in PDT. Photoactivation of anticancer agents offers various advantages like tuning their biological activity and selectivity with reduced dark toxicity. The lanthanide complexes have already attracted considerable interests because of their success in medicinal applications, e.g., as MRI agents. Because of the heavy atom effect the lanthanide complexes are suitable for photobiological applications where excited state photophysics of the photosensitizer play an important role. The redox inactivity of the $\mathrm{Ln}$ (III) cation makes the complexes as poor synthetic chemical nucleases in the presence of reducing cellular thiols. Also, the lanthanide complexes offer additional mechanistic pathways to generate ROS other than singlet oxygen thereby offering a means to circumvent the drawbacks associated with the organic PDT agents. Design and synthesis of lanthanide complexes that could show photoactivated DNA cleavage activity and cytotoxicity in visible light would be highly desirable for their photochemotherapeutic applications in PDT. The chemistry presented in this short review is expected to be useful for designing and developing new generation lanthanide-based photosensitizers for their photochemotherapeutic applications in PDT.

\section{Acknowledgements}

The authors thank the Department of Science and Technology (DST), Government of India, for financial support (SR/S5/MBD-02/2007). ARC thanks DST for JC Bose National Fellowship. Authors also thank Dr. Basudev Maity for his help in drafting the review article.

\section{References}

1. Cotton S A 1991 Lanthanides and actinides; London: Macmillan

2. Moore E G, Samuel A P S and Raymond K N 2009 Acc. Chem. Res. 42542

3. Seitz M, Pluth M D and Raymond K N 2007 Inorg. Chem. 46351

4. New E J, Parker D, Smith D G and Walton J W 2010 Curr. Opin. Chem. Biol. 14238

5. Fricker S P 2006 Chem. Soc. Rev. 35524

6. Thompson K H and Orvig C 2003 Science $\mathbf{3 0 0} 936$

7. Wang K, Li R, Cheng Y and Zhu B 1999 Coord. Chem. Rev. 190-192 297

8. Bünzli J C G and Choppin G R 1989 Lanthanide probes in life, chemical and earth sciences: Theory and practice; Amsterdam: Elsevier

9. Albaaj F and Hutchison A 2003 Drugs 63577

10. Werner E J, Datta A, Jocher C J and Raymond K N 2008 Angew. Chem. Int. Ed. 478568

11. Datta A, Raymond K N 2009 Acc. Chem. Res. 42938

12. Major J L and Meade T J 2009 Acc. Chem. Res. 42893

13. Caravan P 2009 Acc. Chem. Res. 42851

14. Bottrill M, Kwok L and Long N J 2006 Chem. Soc. Rev. 35557

15. Caravan P, Ellison J J, McMurry T J and Lauffer R B 1999 Chem. Rev. 992293

16. New E J, Congreve A and Parker D 2011 Chem. Sci. 1111

17. Montgomery C P, Murrey B S, New E J, Pal R and Parker D 2009 Acc. Chem. Res. 42925

18. New E J and Parker D 2009 Org. Biomol. Chem. 7851 
19. Murrey B S, New E J, Pal R and Parker D 2008 Org. Biomol. Chem. 62085

20. Yu J, Parker D, Pal R, Poole R A and Cann M J 2006 J. Am. Chem. Soc. 1282294

21. Bünzli J C G 2010 Chem. Rev. 1102729

22. Chauvin A S, Comby S, Song B, Vandevyver C D, Thomas F and Bünzli J C G 2007 Chem. Eur. J. 139515

23. Bünzli J C G 2009 Chem. Lett. 38104

24. Deiters E, Song B, Chauvin A S, Vandevyver C D B, Gumy F and Bünzli J C G 2009 Chem. Eur. J. 15885

25. Handl H L and Gillies R J 2005 Life Sci. 77361

26. Xu J, Corneillie T M, Moore E G, Law G L, Butlin N G and Raymond K N 2011 J. Am. Chem. Soc. 13319900

27. Moore E G, Xu J, Jocher C J, Werner E J and Raymond K N 2006 J. Am. Chem. Soc. 12810648

28. Bonnett R 2000 Chemical aspects of photodynamic therapy; London, UK: Gordon \& Breach

29. Dolmans D E J G J, Fukumura D and Jain R K 2003 Nature 3380

30. Celli J P, Spring B Q, Rizvi I, Evans C L, Samkoe K L, Verma S, Pogue B W and Hasan T 2010 Chem. Rev. 110 2795

31. Henderson B W, Busch T M, Vaughan L A, Frawley N P, Babich D, Sosa T A, Zollo J D, Dee A S, Cooper M T, Bellnier D A, Greco W R and Oseroff A R 2000 Cancer Res. 60525

32. Ochsner M 1997 J. Photochem. Photobiol. B 391

33. Szacilowski K, Macyk W, Drzewiecka-Matuszek A, Brindell M and Stochel G 2005 Chem. Rev. 1052647

34. Köpf-Maier P 1999 Anticancer Res. 19493

35. Guo M, Sun H, McArdle H J, Gambling L and Sadler P J 2000 Biochemistry 3910023

36. Strohfeldt K and Tacke M 2008 Chem. Soc. Rev. 371174 (b) Claffey J, Hogan M, Müller-Bunz H, Pampillön C and Tacke M 2008 Chem. Med. Chem. 3729

37. Hartinger C G, Zorbas-Seifried S, Jakupee M A, Kynast B, Zorbas H and Keppler B K 2006 J. Inorg. Biochem. 100891

38. Bergamo A and Sava G 2011 Dalton Trans. 407817

39. Crespy D, Landfester K, Schubert U S and Schiller A 2010 Chem. Commun. 466651

40. Farrer N J, Salassa L and Sadler P J 2009 Dalton Trans. 10690

41. Schatzschneider U 2010 Eur. J. Inorg. Chem. 1451

42. Ostrowski A D and Ford P C 2009 Dalton Trans. 10660

43. Chifotides H T and Dunbar K R 2005 Acc. Chem. Res. 38146

44. Angeles-Boza A M, Chifotides H T, Aguirre J D, Chouai A, Fu P K -L, Dunbar K R and Turro C 2004 J. Med. Chem. 496841

45. Fry N L and Mascharak P K 2011 Acc. Chem. Res. 44 289

46. Detty M R, Gibson S L and Wagner S J 2004 J. Med. Chem. 473897

47. Castano A P, Mroz P and Hamblin M R 2006 Nat. Rev. Cancer 6535

48. Kerr J F, Wyllie A H and Currie A R 1972 Br. J. Cancer 26239

49. Stroh C and Schulze-Osthoff K 1998 Cell Death Differ. 5997

50. Cañete M, Ortega C, Gavalda A, Cristobal J, Juarranz A, Nonell S, Teixido J, Borrell J I, Villanueva A, Rello S and Stockert J C 2004 Int. J. Oncol. 241221
51. Sessler J L and Miller R A 2000 Biochem. Pharmacol. 59733

52. Mody T D, Fu L and Sessler J L 2001 In Progress in inorganic chemistry, (ed) K D Karlin, New York: John Wiley \& Sons, Inc., vol. 49

53. Alexander V 1995 Chem. Rev. 95273

54. Sessler J L, Hemmi G, Mody T D, Murai, Burrell A and Young S W 1994 Acc. Chem. Res. 2743

55. Evens A M 2004 Curr. Opin. Oncol. 16576

56. Evens A M, Lecane P, Magda D, Prachand S, Singhal S, Nelson J, Miller R A, Gartenhaus R B and Gordon L I 2005 Blood 1051265

57. Mehta M P, Rodrigus P, Terhaard C H, Rao A, Suh J, Roa W, Souhami L, Bezjak A, Leibenhaut M, Komaki R, Schultz C, Timmerman R, Curran W, Smith J, Phan S C, Miller R A and Renschler M F 2003 J. Clin. Oncol. 212529

58. Meyers C A, Smith J A, Bezjak A, Mehta M P, Liebmann J, Illidge T, Kunkler I, Caudrelier J M, Eisenberg P D, Meerwaldt J, Siemers R, Carrie C, Gaspar L E, Curran W, Phan S C, Miller R A and Renschler M F 2004 J. Clin. Oncol. 22157

59. Kereiakes D J, Szyniszewski A M, Wahr D, Herrmann H C, Simon D I, Rogers C, Kramer P, Shear W, Yeung A C, Shunk K A, Chou T M, Popma J, Fitzgerald P, Carroll T E, Forer D and Adelman D C 2003 Circulation 1081310

60. Guldi D M, Mody T D, Gerasimchuk N N, Magda D and Sessler J L 2000 J. Am. Chem. Soc. 1228289

61. Frias J C, Bobba G, Cann M J, Hutchison C J and Parker D 2003 Org. Biomol. Chem. 1905

62. Hussain A, Lahiri D, Begum M S A, Saha S, Majumdar R, Dighe R R and Chakravarty A R 2010 Inorg. Chem. 494036

63. Hussain A, Saha S, Majumdar R, Dighe R R and Chakravarty A R 2011 Ind. J. Chem. Sec. A 50A 519

64. Hussain A, Gadadhar S, Goswami T K, Karande A A and Chakravarty A R 2011 Dalton Trans. 41885

65. Hussain A, Gadadhar S, Goswami T K, Karande A A and Chakravarty A R 2012 Eur. J. Med. Chem. 50319. doi:10.1016/j.ejmech.2012.02.011

66. Chen G-J, Qiao X, Tian J-L, Xu J-Y, Gu W, Liu X and Yan S-P 2010 Dalton Trans. 3910637

67. Bencini A and Lippolis V 2010 Coord. Chem. Rev. 254 2096

68. McKinley A W, Lincoln P and Tuite E M 2011 Coord. Chem. Rev. 2552676

69. Toshima K, Takano R, Ozawa T and Matsumura S 2002 Chem. Commun. 212

70. Franklin S J 2001 Curr. Opin. Chem. Biol. 5201

71. Liu C, Wang M, Zhang T and Sun H 2004 Coord. Chem. Rev. 248147

72. Phillips T, Haq I, Meijer A J H M, Adams H, Soutar I, Swanson L, Sykes M J and Thomas J A 2004 Biochemistry $\mathbf{4 3} 13657$

73. Erkkila K E, Odom D T and Barton J K 1999 Chem. Rev. 992777

74. Khan A U 1976 J. Phys. Chem. 802219

75. Delaey E, Van Laar F, De Vos D, Kamuhabwa A, Jacobs P and De Witte P 2000 J. Photochem. Photobiol. B 5527

76. Hofmeier H and Schubert U S 2004 Chem. Soc. Rev. 33 373 
77. McMurtriea J and Dance I 2009 Cryst. Eng. Commun. 111141

78. Constable E C, Housecroft C E, Neuburger M, Schaffner S and Schaper F 2006 Inorg. Chem. Commun. 9616

79. Davidson G J E and Loeb S J 2003 Dalton Trans. 4319

80. Eryazici I, Moorefield C N and Newkome G R 2008 Chem. Rev. 1081834

81. Chelucci G and Thummel R P 2002 Chem. Rev. 102 3129

82. Brunet E, Juanes O and Rodriguez-Ubis J C 2007 Curr. Chem. Biol. 111

83. Zhang P, Wang Y, Liu H and Chen Y 2011 J. Mater. Chem. 2118462

84. Cotton S A, Franckevicius V, How R E, Ahrens B, Ooi L L, Mahon M F, Raithby P R and Teat S J 2003 Polyhedron 221489

85. Drew M G B, Iveson P B, Hudson M J, Liljenzin J O, Spjuth L, Cordier P-Y, Enarsson A, Hill C and Madic C 2000 J. Chem. Soc., Dalton Trans. 821

86. Bekiari V and Lianos P 2006 Langmuir 228602
87. Schubert U S, Hofmeier H and Newkome G R 2006 Modern terpyridine chemistry; Weinheim, Germany: Wiley-VCH

88. Banik B, Sasmal P K, Roy S, Majumdar R, Dighe R R and Chakravarty A R 2011 Eur. J. Inorg. Chem. 1425

89. Gatenby R A and Gillies R J 2004 Nat. Rev. Cancer 4 891

90. Hanif M, Meier S M, Kandioller W, Bytzek A, Hejl M, Hartinger C G, Nazarov A A, Arion V B, Jakupec M A, Dyson P J and Keppler B K 2011 J. Inorg. Biochem. 105 224

91. Tobita S, Arakawa M and Tanaka I 1984 J. Phys. Chem. 882697

92. Tanaka M, Ohkubo K and Fukuzumi S 2006 J. Phys. Chem. A 11011214

93. Mackay F S, Woods J A, Heringová P, Kašpárková J, Pizarro A M, Moggach S A, Parsons S, Brabec V and Sadler P J 2007 Proc. Natl. Acad. Sci. USA 10420743

94. Louie M W, Liu H W, Lam M H C, Lam Y W and Lo K K W 2011 Chem. Eur. J. 178304 